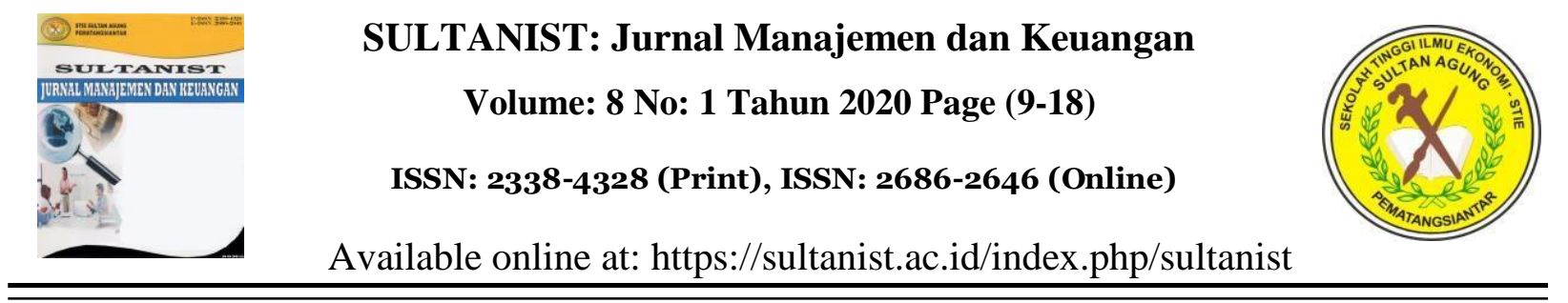

\title{
AKSES PETANI AREN KE LEMBAGA KEUANGAN MIKRO PERDESAAN DI KABUPATEN ROKAN HULU, PROVINSI RIAU
}

\author{
Dahlan Tampubolon \\ Pusat Studi Sosial Ekonomi, LPPM Universitas Riau, Pekanbaru \\ dahlantbolon@unri.ac.id
}

\begin{abstract}
Abstrak
Penelitian ini bertujuan untuk menganalisis karakteristik petani aren yang mengakses dan tidak mengakses Lembaga Keuangan Mikro (LKM). Selain itu memberikan perspektif tentang faktor-faktor yang mempengaruhi keputusan petani untuk mengakses LKM. Wilayah studi di Kabupaten Rokan Hulu termasuk Kecamatan Rambah Samo, Rambah dan Bangun Purba. Sampel 104 petani terdiri dari 58 petani yang mengakses dan 46 petani yang tidak mengakses LKM. Untuk menjelaskan faktor-faktor yang mempengaruhi akses petani aren ke LKM, menggunakan model probabilitas. Model regresi logistik digunakan untuk menganalisis faktor-faktor yang berpengaruh signifikan terhadap akses petani aren ke LKM di wilayah studi. Hasil penelitian ini menemukan bahwa pengeluaran makanan berbeda secara signifikan antara mengakses petani yang mengakses dan bukan yang mengakses LKM. Produksi, jumlah anak yang bersekolah dan pendapatan bersih tahunan dari gula aren, juga berbeda secara signifikan. Studi ini menunjukkan bahwa faktor-faktor yang mempengaruhi petani aren untuk mengakses LKM adalah pendidikan, rasio ketergantungan, jarak, nilai aset cair, dan pendapatan.
\end{abstract}

Kata kunci: Petani Aren, Lembaga Keuangan Mikro

\section{Palm Sugar Farmer's Access to Rural Microfinance Institutions on Rokan Hulu Regency, Riau Province}

Abstract

This research aims to analyze the characteristics of sugar palm farmers who access and not access microfinance institutions (MFIs). Additionally provide a perspective on the factors that influence the decision of farmers to access MFIs. The study areas in Rokan Hulu Regency include Rambah Samo, Rambah and Bangun Purba Subdistricts. A sample of 104 farmers consisted of 58 farmers accessing and 46 farmers not accessing the MFI. To explain the factors that affect sugar palm farmers' access to MFIs, use a probability model. The logistic regression model is used to analyze the factors that a significant influence on the access of sugar palm farmers to the MFI in the study area. The results of this study found that food expenditure differed significantly between accessing farmers and not those accessing MFIs. Production, number of children attending school and annual net income from palm sugar, also differed significantly. This study shows that the factors that influence sugar palm farmers to access MFIs represent education, dependency ratio, distance, liquid asset value and income.

Keywords: Sugar Palm Farmers, Microfinance Institution

Article History: Received: 03 April $2020 \quad$ Revised:06 April $2020 \quad$ Accepted: 23 Mei 2020

Copyright(C)2020, SULTANIST: Jurnal Manajemen dan Keuangan

Sekolah Tinggi Ilmu Ekonomi Sultan Agung 


\section{PENDAHULUAN}

Sektor pertanian merupakan komponen penting di sebagian besar negara berkembang. Sektor ini mempekerjakan lebih dari $60 \%$ populasi dan berpotensi mengurangi kemiskinan pedesaan. Namun, produktivitas pertanian yang rendah tetap menjadi salah satu masalah utama di banyak negara berkembang. Penggunaan terbatas teknologi yang ditingkatkan telah diidentifikasi sebagai faktor utama yang berkontribusi terhadap rendahnya produktivitas pertanian di negaranegara berkembang (Simtowe et al., 2009)

Untuk melakukan modernisasi sektor pertanian, penggunaan input yang ditingkatkan, seperti pupuk, layanan mekanisasi, dan benih sangat penting (Reyes \& Lensink, 2011). Akses ke input yang ditingkatkan sangat tergantung pada ketersediaan kredit yang tepat waktu dan memadai. Terbatasnya akses ke kredit yang memadai bagi petani untuk membeli input yang ditingkatkan tetap menjadi tantangan utama dalam proses produksi pertanian (Simtowe et al., 2009). Situasi ini biasa terjadi di negara-negara berkembang di mana banyak petani kecil diberi kredit, yaitu, permohonan pinjaman ditolak atau jumlah pinjaman dikurangi (Reyes \& Lensink, 2011).

Petani miskin dan petani kecil sering terabaikan, kredit dijatah, atau gagal mengakses program kredit. Ini sebagian dapat dikaitkan dengan gagasan bahwa pertanian skala kecil berisiko (Tadesse, 2014; Weber \& Musshoff, 2013). Awunyo-Vitor et al., (2014), mendapati bahwa keterlibatan dalam kegiatan di luar pertanian, orientasi komersial petani, keseimbangan akun positif, dan peningkatan ukuran pertanian berpotensi mengurangi penyediaan oleh pemberi pinjaman.

Aren sebagai salah satu komoditi pertanian pilihan masyarakat di Kabupaten Rokan Hulu. Sentra produksi gula aren di Kabupaten Rokan Hulu antara lain di Kecamatan Rambah Samo, Rambah dan Bangun Purba. Produksi arenpada tahun 2014 di Kecamatan Rambah Samo sebesar 4,63 ton, Kecamatan Rambah 4,95ton dan Kecamatan Bangun Purba 4,62 ton (BPS Kabupaten
Rokan Hulu, 2016). Nira aren sebagai bahan baku agroindustri gula aren diperoleh dari pohon-pohon aren yang ada di daerah tersebut.

Usaha mikro kecil pedesaan memiliki modal usaha yang tidak mencukupi. Sektor pekerjaan yang memiliki ketergantungan terhadap sumber permodalan adalah sektor industri. Di dalam menjalankan usahanya, sebagian besar usaha mikro kecil menggunakan sumber modal pribadi, baik dari tabungan yang telah dimiliki atau dengan menjual aset yang ada. Semangat berusaha masyarakat pedesaan dalam usaha mikro kecil dan menengah meningkat dengan adanya peran kelembagaan tempatan (Tampubolon, 2013).

Untuk mengisi kesenjangan dalam penyediaan kredit di pedesaan, beragam pendekatan pinjaman inovatif telah dipromosikan oleh Lembaga Keuangan Mikro (LKM). Beberapa LKM Riau memberikan kredit, yang lain menawarkan deposito dan fasilitas kredit, serta yang lain lagi hanya mengumpulkan deposito. Fungsi dan peranan utama LKM adalah sebagai penyedia modal usaha, terutama bentuk Badan Usaha Milik Desa (BUMDes), juga Usaha Simpan Pinjam (USP), dan bank perkreditan rakyat (Tampubolon, 2009).

Rumusan masalah penelitian ini adalah faktor-faktor apa yang memberikan pengaruh terhadap akses petani aren ke LKM. Penlitian ini bertujuan untuk memberikan perspektif tentang faktor-faktor yang mempengaruhi akses petani aren ke LKM. Hasil penelitian ini bermanfaat memberikan wawasan tentang penyediaan kredit pedesaan di Riau, terutama di wilayah studi.

\section{LANDASAN TEORI}

\section{Akses ke Lembaga Keuangan Mikro}

Ada tumpang tindih dalam tiga istilah "kredit pedesaan", "kredit pertanian", dan "kredit mikro" disektor keuangan. Kredit pedesaan mengacu pada layanan kredit di daerah pedesaan yang bertujuan untuk orangorang di semuatingkatpendapatan, sementara kredit pertanian cenderung untuk membiayai kegiatan terkait pertanian (Le Thi Minh, 2014). Keuangan mikro adalah penyediaan layanan keuangan untuk orang miskin dan 
berpenghasilan rendah, di mana petanimemiliki akses ke dana yang terjangkau untuk membiayai kegiatannya untuk menghasilkan pendapatan, membangun aset, memperlancarkonsumsi, dan mengelola risiko.Layanan keuangan meliputi produk kredit (kredit mikro), jugatabungan, transfer uang, dan asuransi (CGAP, 2012).

Akses ke kredit pedesaan dalam beberapa makalah didefinisikan sebagai kesulitan mengakses modal oleh petani miskin (Hinson, 2011). Perbedaan antara dua konsep "akses ke kredit formal" dan "partisipasi dalam program kredit formal" telah ditunjukkan dalam beberapa penelitian. Dalam beberapa kasus, kedua konsep ini digunakan secara bergantian. Namun, perbedaan antara keduanya adalah: partisipasi dalam program kredit adalah masalah yang dapat dipilih petani untuk berpartisipasi, sementara akses ke kredit sering kali menyiratkan hambatan ketika memasuki pasar.

\section{Penentu Akses Kredit Pedesaan}

Sumber kredit di sebagian besar negara umumnya diklasifikasikan dalam tiga kategori: kredit formal, semi formal, dan informal. Sumber formal adalah kredit dari bank komersial atau sejumlah dana kredit. Kredit informal berasal dari kerabat, pemberi pinjaman perorangan, dan asosiasi. Sektor semi formal termasuk LKM, program pinjaman yang didukung pemerintah yang ditujukan untuk bagian-bagian tertentu dari populasi, dan proyek-proyek non-pemerintah lainnya (Diagne \& Zeller, 2001)

Wulandari et al (2017), menemukan persyaratan penting untuk memperoleh keuangan di antara jenis penyedia keuangan. Bank dan LKM sama-sama memberikan kredit dengan fokus pada persyaratan yang berbeda. Lembaga Keuangan Mikro memiliki fokus pada karakter dan pengetahuan tentang aplikasi keuangan. Untuk mendapatkan akses ke keuangan non-tunai, asosiasi petani mengharuskan petani untuk memiliki keanggotaan asosiasi terdaftar.

\section{Dampak Sosial dan Ekonomi dari Akses Kredit di Daerah Pedesaan}

Akses ke lembaga kredit dan pertumbuhan produktivitas memiliki hubungan positif di antara petani tanaman pangan subsisten (Ugwumba \& Omojola, 2013). Kelembagaan, penyuluhan dan kredit memberi dampak signifikan pada efisiensi (Djoumessi, Afari-Sefa, et al., 2018). Namun penyaluran kredit melalui usaha ekonomi pedesaan simpan pinjam (UED-SP) sering tidak lancar pengembaliannya dan penyaluran kredit tidak tepat sasaran (Tampubolon \& Basri, 2008).

Ahmad (2011), menyatakan bahwa kredit hanya memiliki peran tidak langsung dalam meningkatkan hasil pertanian melalui pembelian berbagai input. Das (2018), telah mempelajari dampak kredit terhadap pengurangan kemiskinan dalam hal akses kredit formal, semi formal, dan informal. Nilai tukar petani menentukan kemiskinan melalui konsumsi pangannya. Petani pemilik lahan lebih rendah subsistensinya dibanding penggarap (Mardiana et al., 2019).

$$
\text { Rahman et al (2014), }
$$

menggunakan model regresi logistik untuk menganalisis dampak kredit pertanian terhadap produktivitas pertanian.Ada hubungan positif antara kredit dan produktivitas pertanian menunjukkan bahwa kredit memungkinkan para petani untuk membeli benih dengan kualitas unggul atau varietas unggul, pupuk dan pestisida dan hasil pertanian meningkat karena input yang tepat waktu dan memadai.

\section{METODE PENELITIAN}

Studi ini dilakukan di Kabupaten Rokan Hulu, meliputi Kecamatan Rambah Samo, Rambah dan Bangun Purba. Kecamatan tersebut dipilih berdasarkan pentingnya pertanian aren sebagai mata pencaharian banyak petani. Pengambilan sampel berstratifikasi digunakan untuk memilih petani individu dari mana kesimpulan diambil. Stratifikasi dicapai dengan mengelompokkan petani menjadi kelompok yang dibedakan kepemilikan lahan tanaman aren. Selanjutnya, petani yang sama diciutkan ke dalam tipologi masing-masing pengakses LKM dan nonpengakses. Petani pengakses LKM sebanyak 
58 petani dan non-pengakses 46 petani aren. Pemilihan dua kategori ini memungkinkan penilaian perbedaan dalam mengakses peluang keuangan. Kategori dihitung sesuai konsep ketepatan dan kepercayaan menggunakan rumus yang disediakan oleh (Sarantakos, 2013).

Pendekatan kualitatif analisis data (deskripsi, teks tematik dan analisis gambar) digunakan untuk menganalisis data dari diskusi kelompok terarah. Data ini dianalisis saat dikumpulkan, hingga jelas bahwa perspektif sedang diulang dan saturasi data telah tercapai seperti yang disediakan oleh (Teddlie \& Tashakkori, 2009). Data kuantitatif dianalisis menggunakan t-tes, Frasio dan statistik deskriptif (persentase dan rata-rata).

\section{PEMBAHASAN}

\section{Model Empiris}

Untuk memperkirakan faktor-faktor yang mempengaruhi akses petani aren ke LKM, menggunakan model probabilitas. Studi oleh (Asante-Addo et al., 2016; Lukytawati, 2009; Mpiira et al., 2013) menetapkan akses ke LKMsebagai fungsi karakteristik petani.Metode ini dipilih karena merupakan metode analisis standar ketika variabel hasil dikotomis yang diukur memiliki nilai 1 atau 0 , di mana $1=$ mengakses dan $0=$ tidak mengakses (Hosmer et al., 2013)

Model regresi logistik digunakan untuk menentukan faktor-faktor yang memiliki pengaruh signifikan terhadap akses petani aren keLKM wilayah studi.

$$
A_{i}^{*}=\beta_{0}+\sum_{i=1}^{n} \beta_{i} X_{k i}+\varepsilon
$$

Di mana $\beta_{0}$ adalah istilah intersep, dan $\beta_{1}, \beta_{2}, \beta_{3}, \ldots \beta_{i}$, adalah koefisien yang terkait dengan masing-masing variabel penjelas $X_{1}$, $X_{2}, \quad X_{3}, \ldots X_{i}$. Akses ke LKM atau kemungkinan bahwa petani akanmengakses dengan adanya faktor-faktor ini $\left(X_{i}\right)$ diberikan oleh:

$$
P_{i}=\frac{e^{U_{i}}}{1+e^{u_{i}}}
$$

Akses petani aren ke LKM adalah 1, maka (1 $\left.-P_{i}\right)$ adalah probabilitas bahwa aksesibilitas petani adalah 0 . Peluang $(A=1$ versus $A=0)$ yang akan digunakan dapat didefinisikan sebagai rasio probabilitas bahwa petani memiliki akses $\left(P_{i}\right)$ dengan probabilitas nonakses $\left(1-P_{i}\right)$ yaitu $\frac{P_{i}}{1-P_{i}}$. Mengambil $\log$ natural, persamaan prediksi untuk petani ke- $i$ dinyatakan sebagai:

$$
\begin{aligned}
A=\ln \left(\frac{P_{i}}{1-P_{i}}\right) & =\ln \text { odds } \\
= & \beta_{0} \\
+ & \sum_{i=1}^{n} \beta_{i} X_{k i}+\varepsilon=A_{i}^{*}
\end{aligned}
$$

Di mana $\mathrm{P}_{\mathrm{i}}$ menunjukkan probabilitas bahwa ke- $i$, dan $A_{i}^{*}$ juga disebut sebagai log dari odds ratio yang mendukung akses kredit.

\section{Variabel yang digunakan dalam model empiris}

Pilihan variabel bebas yang digunakan didasarkan pada teori, penelitian sebelumnya, dan ketersediaan data. Literatur menunjukkan bahwa akses petani kecil ke LKM dipengaruhi oleh sejumlah faktor, seperti jenis kelamin, usia, status pendidikan, pendapatan bulanan, keamanan hak atas tanah, nilai aset, tabungan, pengiriman uang dan pensiun, rasio dependensi, kapasitas pembayaran dan modal sosial. Faktor-faktor ini penting dalam dua cara karena dapat mempengaruhi permintaan kredit petani; dan calon pemberi pinjaman cenderung mendasarkan penilaiannya atas kelayakan kredit peminjam pada karakteristik ini. Karena variabel bebas yang termasuk dalam model logit adalah hasil dari ekspektasiex, tidak ada pra-keputusan yang jelas tentang tanda-tanda variabel yang berpengaruh pada akses ke LKM. Variabel bebas yang digunakan untuk mengidentifikasi faktorfaktor penentu petaniaren mengakses LKMdisajikan pada Tabel 1.

Tabel 1. Deskripsi Variabel dan Pengaruhnya Terhadap Akses Petani Lembaga Keuangan Mikro

\begin{tabular}{|l|l|c|}
\hline $\begin{array}{c}\text { Variabel } \\
\text { Independen }\end{array}$ & Deskripsi & Hipotesis \\
\hline Usia & $\begin{array}{l}\text { Usia Petani (tahun), } \\
\text { (Gilligan et al, 2005) }\end{array}$ & $+/-$ \\
\hline Jenis kelamin & $\begin{array}{l}\text { Jenis kelamin kepala } \\
\text { rumah tangga petani (1 = } \\
\text { laki-laki, 0 = perempuan) }\end{array}$ & $+/-$ \\
\hline
\end{tabular}




\begin{tabular}{|l|l|c|}
\hline & (Simtowe et al, 2009) & + \\
\hline Pendidikan & $\begin{array}{l}\text { Pendidikan yang } \\
\text { diselesaikan bertahun- } \\
\text { tahun oleh petani (Gilligan } \\
\text { et al, 2005 dan Simtowe et } \\
\text { al, 2009) }\end{array}$ & + \\
\hline $\begin{array}{l}\text { Rasio } \\
\text { Ketergantungan }\end{array}$ & $\begin{array}{l}\text { Rasio ketergantungan } \\
\text { (anggota rumah tangga } \\
\text { 15 tahun dan > 64 tahun) } \\
\text { (Omonona et al, 2010) }\end{array}$ & + \\
\hline $\begin{array}{l}\text { Ukuran } \\
\text { Pertanian }\end{array}$ & $\begin{array}{l}\text { Ukuran pertanian (hektar) } \\
\text { (Gilligan et al, 2005 dan } \\
\text { Simtowe et al, 2009) }\end{array}$ & + \\
\hline Jarak & $\begin{array}{l}\text { Jarak ke LKM formal } \\
\text { terdekat (Gilligan et al, } \\
\text { 2005 dan Chisasa, 2016) }\end{array}$ & + \\
\hline Aset cair & $\begin{array}{l}\text { Nilai aset likuid (Gilligan } \\
\text { et al, 2005) }\end{array}$ & + \\
\hline Pendapatan & $\begin{array}{l}\text { Total pendapatan rumah } \\
\text { tangga tahun sebelumnya } \\
\text { (Rp) (Gilligan et al, 2005 }\end{array}$ & + \\
\hline Rasio leverage & $\begin{array}{l}\text { Rasio hutang formal } \\
\text { rumah tangga dari } \\
\text { pendapatan tahun lalu } \\
\text { (Akpan et al, 2013) }\end{array}$ & + \\
\hline Sumber: Hasil Stud Lapangan (2020) & + \\
\hline Sal & + \\
\hline
\end{tabular}

Sumber: Hasil Studi Lapangan (2020)

\section{Karakteristik Petani Aren dan \\ Pemanfaatan Lembaga Keuangan Mikro}

Hasil pada Tabel 2 menunjukkan bahwa ada perbedaan yang signifikan $(\mathrm{P} \leq 0,05)$ antara tingkat pendidikan petani aren yang mengakses keuangan pertanian dan petani yang tidak mengakses keuangan. Petani yang mengakses keuangan memiliki pendidikan hampir satu tahun lebih tinggi dibandingkan dengan petani yang tidak mengakses keuangan. Hal ini disebabkan oleh kenyataan bahwa pendidikan memberdayakan petani untuk membuat keputusan berdasarkan informasi dan mengidentifikasi peluang pasar di mana petani berada.

Kemampuan petani untuk memproduksi lebih efisien dan menjual lebih banyak produk di pasar sangat tinggi dan positif terkait dengan tingkat pendidikan petani (Muslimah et al., 2017). Petani, yang telah mencapai pendidikan menengah dan telah menggabungkannya dengan pendidikan informal, lebih cenderung menghasilkan dan menjual lebih banyak.Petani aren memperoleh kredit dari LKM dengan beban bunga yang sangat tinggi, namun petani tidak dibebani administrasi yang menyulitkan. Rata-rata suku bunga pinjaman yang menjadi beban petani mencapai 19,22\%. Pinjaman petani umumnya tanpa agunan dan dilaksanakan oleh para tengkulak, rentenir dan juga LKM milik desa (seperti BUMDes). Masa cicilan pinjaman petani antara satu hingga dua tahun dengan rata-rata mencapai 19,5 bulan.

Tabel 2. Karakteristik Petani Aren Dalam Mengakses Lembaga Keuangan Mikro

\begin{tabular}{|c|c|c|c|c|}
\hline No & Karakteristik & Peminjam & $\begin{array}{c}\text { Bukan } \\
\text { Peminjam }\end{array}$ & Total \\
\hline 1 & $\begin{array}{l}\text { Usia Petani } \\
\text { (tahun) }\end{array}$ & 45,69 & 42,96 & 44,46 \\
\hline 2 & $\begin{array}{l}\text { Pendidikan } \\
\text { Kepala Rumah } \\
\text { Tangga (tahun) }\end{array}$ & 7,89 & 7,08 & 7,53 \\
\hline 3 & $\begin{array}{l}\text { Rata-rata bunga } \\
\text { pinjaman }(\%)\end{array}$ & 19,22 & & \\
\hline 4 & $\begin{array}{l}\text { Jumlah belanja } \\
\text { makanan harian } \\
\text { (Rp ribu) }\end{array}$ & $21,16^{*}$ & 18,82 & 20,11 \\
\hline 5 & $\begin{array}{l}\text { Rata-rata lama } \\
\text { pengembalian }\end{array}$ & 19,50 & & \\
\hline 6 & $\begin{array}{l}\text { Produksi gula } \\
\text { aren (ton) }\end{array}$ & $2,76^{*}$ & 2,45 & 2,62 \\
\hline 7 & $\begin{array}{l}\text { Jumlah anak } \\
\text { bersekolah }\end{array}$ & $2,18 *$ & 1,75 & 1,99 \\
\hline 8 & $\begin{array}{l}\text { Ukuran rumah } \\
\text { tangga }\end{array}$ & 5,86 & 5,41 & 5,66 \\
\hline 9 & $\begin{array}{l}\text { Pendapatan } \\
\text { bersih tahunan } \\
\text { (Rp juta) }\end{array}$ & $51,25^{*}$ & 45,36 & 48,60 \\
\hline
\end{tabular}

Sumber: Hasil Studi Lapangan (2020)

Hasil pada Tabel2 di atas lebih lanjut menunjukkan bahwa petani yang mengakses keuangan pertanian memiliki jumlah belanja makanan harian yang secara signifikan $(\mathrm{P} \leq$ $0,05)$ lebih tinggi dibandingkan dengan petani yang tidak mengakses. Para petani yang mengakses keuangan dapat membeli Rp. 21.160 makanan dibandingkan dengan $\mathrm{Rp}$. 18.820 bagi petani yang belum mengakses keuangan. Penjelasan untuk hasil ini adalah bahwa petaniaren yang mengakses LKMmampu meningkatkan produksi yang memungkinkan petani untuk membelanjakan makanan banyak per hari dibandingkan dengan petani yang tidak mengakses LKM. Hasil ini didukung oleh temuan Annim \& Frempong (2018), bahwa peningkatan kredit yang 
tersedia untuk sektor pertanian sangat meningkatkan kegiatan produksi pertanian.

Petani yang telah mengakses keuangan pertanian ditemukan memiliki jumlah anak yang secara signifikan lebih tinggi di sekolah daripada yang tidak mengakses keuangan, seperti yang ditunjukkan pada Tabel 2 di atas. Kelompok pertama memiliki rata-rata 2,18 anak di sekolah sementara yang terakhir memiliki 1,75 anak. Hasil ini menunjukkan fakta bahwa jumlah anak di sekolah semakin meningkat dengan kebutuhan keuangan untuk biaya sekolah dan persyaratan lain yang mendorong petani mencari dana untuk memenuhi kebutuhan pendidikan (Pelimina \& Urassa, 2015; Sebatta et al., 2014).

Terkait dengan hal di atas, tak ada perbedaan yang signifikan antara ukuran rumah tangga para petani yang mengakses keuangan pertanian dan petani yang tidak mengakses. Hasil pada Tabel 2 menunjukkan bahwa petani yang mengakses keuangan pertanian memiliki ukuran rumah tangga yang lebih besar daripada petani yang tidak mengaksesnya. Alasan untuk ini adalah bahwa dengan keluarga yang lebih besar, petani cenderung mencari cara untuk meringankan beban konsumsi dengan meminjam pada saat kelangkaan. Penjelasan yang diberikan adalah bahwa dalam banyak kasus ukuran rumah tangga yang lebih besar adalah karena anggota tidak produktif yang memberikan banyak tekanan pada beberapa orang yang mendapatkan penghasilan.

Petani aren di Kabupaten Rokan Hulu, Provinsi Riau rata-rata menghasilkan gula aren sebanyak 2,62 ton per tahun dengan pendapatan bersih tahunan mencapai Rp. 48,6 juta. Terdapat perbedaan yang signifikan antara petani aren yang mengakses LKM dengan petani yang tidak mengakses. Per tahun, petani aren yang mengakses LKM memperoleh pendapatan bersih sebesar RP. 51,25 juta lebih besar dibandingkan dengan petani yang tidak mengakses yang memperoleh pendapatan bersih rata-rata $\mathrm{Rp}$. 45,36 juta. Perbedaan ini sesuai dengan apa yang ditemukan Annim \& Frempong (2018), bahwa petani yang memperoleh kredit mampu meningkatkan kegiatan produksinya.

\section{Faktor-Faktor yang Mempengaruhi Keputusan Petani Aren untuk Mengakses Lembaga Keuangan Mikro Pedesaan}

Hasil pada Tabel 3 menunjukkan parameter yang mempengaruhi keputusan petani aren untuk mencari dan mengakses lembaga keuangan mikto. Hasil penelitian menunjukkan bahwa tingkat pendidikan petani memiliki pengaruh positif dan signifikan $(\mathrm{P} \leq$ 0,05) pada keputusan untuk mengakses LKM. Ini berarti bahwa petani yang berpendidikan memiliki kapasitas untuk membaca sinyal pasar keuangan seperti suku bunga dan ketentuan pembayaran dan merasa berani untuk mencari kredit. Selain itu, pendidikan memberdayakan peminjam dengan percaya diri karena petani dapat memiliki rencana yang jelas tentang cara menginvestasikan dana. Diagne \& Zeller (2001), juga menemukan pengaruh positif tingkat pendidikan petani dan keputusan untuk mengakses lembaga keuangan. Kajian lain juga menjelaskan fakta bahwa pendidikan memungkinkan para pembuat keputusan, yang dalam kebanyakan kasus adalah petani untuk membuat keputusan yang tepat mengenai pinjaman (Simtowe et al., 2009). Pada tingkat pendidikan tertentu, seorang petani dapat membuat keputusan berdasarkan informasi mengenai jumlah yang diperlukan untuk melakukan proyek tertentu melalui membuat rencana bisnis atau anggaran. Namun ada kajian yang menemukan bahwa pendidikan tidak memiliki pengaruh atas akses petani terhadap LKM (Anang et al., 2015).

Hasil lebih lanjut menunjukkan bahwa angka ketergantungan dalam rumah tangga memiliki pengaruh positip dan signifikan $(\mathrm{P} \leq$ 0,01) pada keputusan untuk mengakses lembaga keuangan. Hasil ini menunjukkan bahwa ketergantungan dalam rumah tangga yang lebih besar mendorong petani aren untuk mencari pembiayaan pertanian karena banyaknya permintaan yang diterima petani. Oleh karena itu, para petani cenderung menjadi lebih berorientasi ekonomi dan mencari kredit. Omonona et al (2010), menemukan ketergantungan mendorong adanya keinginan meningkatkan produksi melalui sumber pembiayaan luar. 
Tabel 3. Faktor-Faktor yang Mempengaruhi Petani Aren Mengakses Lembaga Keuangan Mikro

\begin{tabular}{|c|l|c|c|}
\hline No & \multicolumn{1}{|c|}{ Variabel } & Koefisien & thit \\
\hline 1 & Usia & -0.0009 & -1.025 \\
\hline 2 & Jenis Kelamin & -0.7307 & -1.354 \\
\hline 3 & Pendidikan & 0.0299 & 2.065 \\
\hline 4 & $\begin{array}{l}\text { Rasio } \\
\text { Ketergantungan }\end{array}$ & 0.0006 & 2.965 \\
\hline 5 & Ukuran & -0.3256 & -1.754 \\
\hline 6 & Jarak & -0.0654 & -2.251 \\
\hline 7 & Aset Cair & -0.0001 & 3.051 \\
\hline 8 & Pendapatan & -0.0303 & 2.105 \\
\hline 9 & Rasio Leverage & -0.0019 & 1.546 \\
\hline
\end{tabular}

Sumber: Hasil Studi Lapangan (2020)

Lokasi rumah memberikan pengaruh terhadap akses LKM(Anang et al., 2015). Di Kabupaten Rokan Hulu menunjukkan bahwa jarak rumah petani aren dengan lokasi LKM berpengaruh negatif dan signifikan pada keputusan petani mengakses lembaga keuangan. Kajian lain menemukan arah yang berbeda, makin jauh maka makin berpeluang mengakses (Djoumessi, Kamdem, et al., 2018).

Nilai aset cair (yaitu, nilai total semua sepeda, sepeda motor, mobil, lemari es, televisi dan kompor gas/listrik) dan ternak, serta pendapatan tahun sebelumnya dari rumah tangga pertanian dapat digunakan sebagai indikator kepemilikan aset cair. Pemberi kredit akan lebih terbuka kepada petani yang memiliki aset cair lebih besar karena aset petani dapat lebih mudah dilikuidasi untuk mengimbangi hutang (Gilligan et al., 2005). Kajian di Kabupaten Rokan Hulu menunjukkan besarnya aset cair memperbesar peluang akses ke LKM.

Hasil kajian ini juga menemukan bahwa besaran pendapatan memperbesar pelung petani aren mengakses LKM. Hal ini berbeda dengan temuan Asante-Addo (2016), bahwa petani dengan pendapatan yang lebih kecil lebih berpeluang memperoleh penjatahan kredit. Demikian pula dengan kajian Awunyo-Vitor et al (2014) menemukan bahwa pendapatan petani dari tahun sebelumnya mengurangi kemungkinan penjatahan kredit. Petani Aren di Rokan Hulu bukan sebagai penerima program kredit.Para petani memperoleh kredit bukan dari program KUR. Petani yang berpendapatan tinggi lebih berpeluang mengakses LKM.

\section{KESIMPULAN DAN SARAN}

\section{Kesimpulan}

Penelitian ini mengkaji karakteristik petani aren pengakses LKM dan bukan pengakses LKM memberikan perspektif tentang faktor-faktor yang mempengaruhi akses petani aren ke LKM di Kabupaten Rokan Hulu, Provinsi Riau. Tidak ada perbedaan rata-rata usia petani, pendidikan kepala rumah tangga dan ukuran keluarga antara petani aren pengakses dan bukan pengakses LKM. Petani aren yang mengakses LKM membelanjakan uangnya untuk makanan berbeda signifikan dengan petani yang tidak mengakses LKM. Perbedaan yang signifikan juga pada karakteristik jumlah produksi, jumlah anak bersekolah dan pendapatan bersih tahunan dari gula aren.Kajian ini menunjukkan bahwa faktor yang mempengaruhi petani aren semakin besar peluang mengakses LKM adalah pendidikan, rasio ketergantungan, nilai aset cair yang dimiliki dan pendapatan petani aren. Semakin jauh jarak rumah petani aren dengan lokasi LKM, semakin kecil peluang untuk mengaksesnya.Variabel penjelas lainnya yang dimasukkan ke dalam model tidak memberikan pengaruh yang signifikan terhadap peluang petani mengakses LKM di Kabupaten Rokan Hulu, Provinsi Riau.

\section{Saran}

Temuan ini memiliki beberapa implikasi bagi petani aren untuk mengakses LKM. Perlu untuk mengimplementasikan program literasi keuangan orang dewasa oleh otoritas jasa keuangan (OJK) dan mitra pembangunan pedesaan. Program semacam itu akan memberikan pendidikan bagi petani aren tentang kredit dan manajemen bisnis hasil pertanian. Temuan ini juga merekomendasikan bahwa LKM formal harus didorong untuk mengganti jaminan fisik dengan jaminan sosial melalui strategi tanggung jawab kelompok. Ini akan menambah pendapatan, meningkatkan 


\section{SULTANIST: Jurnal Manajemen dan Keuangan, Vol 8 (1), 2020}

kemampuan pembayaran, dan memberdayakan rumah tangga petani untuk berpartisipasi dalam program kredit. Temuan ini memiliki implikasi yang relevan dengan kebijakan nasional untuk memperluas akses keuangan bagi petani di pedesaan.

\section{Daftar Pustaka}

Ahmad, N. (2011). Impact of Institutional Credit on Agricultural Output. Pakistan Development Review, 24(2), 469-485. https://doi.org/10.30541/v42i4IIpp.469485

Anang, B. T., Sipiläinen, T., Bäckman, S., \& Kola, J. (2015). Factors influencing smallholder farmers' access to agricultural microcredit in Northern Ghana. African Journal of Agricultural Research, 10(24), 2460-2469. https://doi.org/10.5897/AJAR2015.9536

Annim, S. K., \& Frempong, R. (2018). Effects of access to credit and income on dietary diversity in Ghana. Food Security, 10(6), 1649-1663.

https://doi.org/10.1007/s12571-0180862-8

Asante-Addo, C., Mockshell, J., Siddig, K., \& Zeller, M. (2016). Agricultural credit provision: What really determines farmers' participation and credit rationing? The 5th International Conference of the African Association of Agricultural Economists, 1-25.

Awunyo-Vitor, D., Al-Hassan, R. M., Sarpong, D. B., \& Egyir, I. (2014). Agricultural credit rationing in Ghana: what do lenders look for? Agricultural Finance Review, 74(3), 364-378. https://doi.org/10.1108/AFR-01-20130004

BPS Kabupaten Rokan Hulu. (2016). Kabupaten Rokan Hulu Dalam Angka 2015. Badan Pusat Statistik.

CGAP. (2012). A Guide to Regulation and Supervision of Microfinance. CGAP.

Das, T. (2018). Does credit access lead to expansion of income and multidimensional poverty? A study of rural Assam. International Journal of Social Economics, 26(2), 252-270. https://doi.org/10.1108/IJSE-12-20170592

Diagne, A., \& Zeller, M. (2001). Access to credit and its impact on welfare in Malawi. International Food Policy Research Institute.

Djoumessi, Y., Afari-Sefa, V., Kamdem, C., \& Bidogeza, J. (2018). Socio-economic and institutional factors underlying efficiency of smallholder vegetable farms in Southwest region of Cameroon. International Journal of Social Economics, 45(1), 93-106. https://doi.org/10.1108/IJSE-09-20160256

Djoumessi, Y., Kamdem, C., Afari-sefa, V., \& Bidogeja, J. (2018). Determinants of smallholder vegetable farmers credit access and demand in Southwest region, Cameroon. Economics Bulletin, Accessecon LLC. s.L., 38(2), 1231-1240. http://hdl.handle.net/10419/179942

Gilligan, D. O., Harrower, S., \& Quisumbing, A. (2005). How Accurate is Reports of Credit Constraints? Reconciling Theory with Respondents' Claims in Bukidnon, Phillipines. International Food Policy Research Institute.

Hinson, R. E. (2011). Banking the poor: the role of mobiles. Journal of Financial Services Marketing, 15(4), 320-33. https://doi.org/10.1057/fsm.2010.29

Hosmer, D. W., Lameshow, S., \& Sturdivant, R. X. (2013). Applied Logistic Regression (3rd ed.). John Wiley and Sons.

Le Thi Minh, C. (2014). An analysis of access to credit by animal producing households in Hai Duong Province, Vietnam [Université de Liège Gembloux]. https://orbi.uliege.be/handle/2268/164351

Lukytawati, A. (2009). Factors Influencing Participation and Credit Constraints of a Financial Self-Help Group in a Remote Rural Area: The Case of ROSCA and ASCRA in Kemang Village West Java. Journal of Applied Sciences, 9(1), 2067- 
2077.

https://doi.org/10.3923/jas.2009.2067.20 77

Mardiana, Iyan, R. Y., \& Zamaya, Y. (2019). Konsumsi dan tingkat subsistensi petani di Kampung Sei Berbari, Kecamatan Pusako, Kabupaten Siak Provinsi Riau. Sorot, 14(2), 50-63. https://doi.org/10.31258/sorot.14.2.\%25p

Mpiira, S., Kiiza, B., Staver, C., Tabuti, J. R., Katungi, E., Kyotalimye, M., \& Muwumba, P. (. (2013). Factors influencing households participation in the Savings and Credit Cooperative (SACCO) programmes in Uganda. African Journal of Agricultural Research, 8(43), 5280-5288. https://doi.org/10.5897/AJAR11.1673

Muslimah, S., Maharani, E., \& Edwina, S. (2017). Analisis Efisiensi Pemasaran Dan Mutu Gula Aren Di Kabupaten Kuantan Singingi. Jurnal Dinamika Pertanian, 33(3), 243-250. https://doi.org/10.25299/dp.2017.vol33(3 ).3837

Omonona, B. T., Lawal, J. O., \& Oyinlana, A. O. (2010). Determinants of credit constraint conditions and production efficiency among farming households in Southwestern Nigeria. AAAE Third Conference/AEASA 48th Conference, September 19-23, 1-14. https://doi.org/10.22004/ag.econ.95775

Pelimina, B. M., \& Urassa, J. (2015). The contribution of farmers organizations to smallholder farmers well-being: A case study of Kasulu district, Tanzani. African Journal of Agricultural Research, 10(23), 2343-2349. https://doi.org/10.5897/AJAR2014.9261

Rahman, S., Hussain, A., \& Taqi, M. (2014). Impact of agricultural credit on agricultural productivity in Pakistan: An empirical analysis. International Journal of Advanced Research in Management and Social Sciences, 3(4), 125-139. https://www.semanticscholar.org/paper/I mpact-of-agricultural-credit-onagricultural-in-An-Rahman-
Hussain/6dc5bdc77267f234d79424e1163 a705f743dda52

Reyes, A., \& Lensink, R. (2011). The Credit Constraints of Market-Oriented Farmers in Chile. Journal of Development Studies, 47(12), 1851-1868. https://doi.org/10.1080/00220388.2011.5 79111

Sebatta, C., Wamulume, M., \& Mwansakilwa, C. (2014). Determinants of smallholder farmers' access to agricultural finance in Zambia. Journal of Agricultural Science, 6(11), 63-73. https://doi.org/10.5539/jas.v6n11p63

Simtowe, F., Zeller, M., \& Diagne, A. (2009). The impact of credit constraints on the adoption of hybrid maize in Malawi. Review of Agricultural and Environmental Studies, 90(1), 5-22. https://doi.org/10.22004/ag.econ.51627

Tadesse, M. (2014). Fertilizer adoption, credit access, and safety nets in rural Ethiopia. Agricultural Finance Review, 74(3), 290310. https://doi.org/10.1108/AFR-092012-0049

Tampubolon, D. (2009). Lembaga Keuangan Mikro Pedesaan Di Kabupaten Bengkalis. Jurnal Ekonomi, 17(1), 46-61.

Tampubolon, D. (2013). Strategi pemberdayaan masyarakat pesisir di Kabupaten Kepulauan Meranti. Sorot, $8(2)$, $153-161$. https://doi.org/10.31258/sorot.8.2.2358

Tampubolon, D., \& Basri, S. (2008). Kebijakan pembangunan ekonomi kerakyatan: Program budget sharing di Kabupaten Kampar. Jurnal Ekonomi, 16(2), 46-57.

Teddlie, C., \& Tashakkori, A. (2009). Foundations of Mixed Methods Research: Integrating Quantitative and Qualitative Approaches in the Social and Behavioral Sciences. SAGE Publication.

Ugwumba, C. O., \& Omojola, J. T. (2013). Credit access and productivity growth among subsistence food crop farmers in Ikole local government area of Ekiti 
State, Nigeria. Journal of Agricultural and Biological Science, 8(4), 351-356.

Weber, R., \& Musshoff, O. (2013). Can flexible microfinance loans improve credit access for farmers? Agricultural Finance Review, 73(2), 255-271. https://doi.org/10.1108/AFR-09-20120050

Wulandari, E., Meuwissen, M. P. M., Karmana, M. H., \& Oude Lansink, A. G. J. M. (2017). Access to finance from different finance provider types: Farmer knowledge of the requirements. PLoS ONE, 12(9), e0179285. https://doi.org/10.1371/journal.pone.017 9285

\section{Profil Singkat}

Dahlan Tampubolon, merupakan Koordinator Pusat Studi Sosial Ekonomi, LPPM Universitas Riau dan dosen tetap Program Studi Ekonomi Pembangunan Universitas Riau. Pendidikan doktor bidang Ekonomi Pembangunan Wilayah. 